UDK 821.111(73)-31.09Faulkner W.

\title{
FAULKNER'S SOUTHERN BELLE - MYTH OR REALITY?
}

\author{
Nataša Intihar Klančar
}

\begin{abstract}
The article deals with heroines of William Faulkner's novels Light in August, Absalom, Absalom!, The Sound and the Fury, The Unvanquished, The Town and his short story "A Rose for Emily." The Southern belle features as a recurring character in Faulkner's fiction, her fragility, modesty, weakness yet strength, beauty, sincerity, generous nature, status and her fall from innocence comprise her central characteristics. Confronted with various expectations of Southern society and with the hardships of war, the belle is faced with many obstacles and challenges.

Faulkner's heroines face a wide array of problems that prevent them from being and/or remaining a Southern belle. Let us name a few: Lena's inappropriate social status, Joanna's wrong roots, Mrs. Hightower's inability to fulfill her duties as the minister's wife, Ellen's miserable marriage, Judith's sad love life, Rosa's feelings of inferiority and humiliation, Mrs. Compson's failure as a mother, Caddy's weak rebellion against male convention, Drusilla's male characteristics, Linda's unrequited love and Emily's dark secret, to name a few.

Through these characters and their destinies Faulkner shows a decaying South whose position has changed considerably over the years. Can the Southern belle save it? Can she save herself?
\end{abstract}

Key words: William Faulkner, Southern belle, myth, Southern literature

The term Southern belle (derived from the French word belle, 'beautiful') is an archetype for a young woman of the American Old South's upper class. The ideal of the Southern belle evolved in the 1930s and it combined positive characteristics and described a perfect daughter, sister, mother, wife and life companion. Typical Southern beauty was not her only distinction, she was accompanied by other virtues as well, the most prominent being devotion to her family and husband, modesty, respect of ancestors, fragility and tenderness.

The image of a perfect woman combines fragility and weakness on one and a certain amount of bravery, persistence and emotional strength to overcome daily problems on the other side. As Anne Goodwyn Jones states in The Encyclopedia of Southern Culture the jobs and duties of a Southern lady are

satisfying her husband, raising the children, meeting the demands of the family's social position, and sustaining the ideals of the South. Her 
strength in manners and morals is contingent, however, upon her submission to the source - God, the patriarchal church and her husband - and upon her staying out of the public life, where she might interfere in their formulation. $(1527,1528)$

The description of a Southern belle would incorporate characteristics such as: the belle is a privileged white girl at the glamorous and exciting period between being a daughter and becoming a wife. She is the fragile, dewy, just-opened bloom of the southern female: flirtatious but sexually innocent, bright but not deep, beautiful as a statue or painting or porcelain but like each risky to touch. She "epitomize[s] Southern hospitality, cultivation of beauty and a flirtatious yet chaste demeanor" (Wikipedia: 2011).

The Southern belle was thus a woman put on the pedestal and as a true beauty she had to be protected by the men, especially from their sexual advances, harasses and maybe even attacks. Sexual relations before getting married were not approved of by the society, nor were there any sorts of affairs that the ladies could have engaged into. The story itself was quite different, to be sure, depending largely on the ones referred to - be it men (married or single) or women. Men's affairs and sexual conquest in a way contributed to their image of masculinity. Similar double standards were applied to racial relations. Victorian society strongly disapproved of a relationship between a white woman and a black man, whereas white men often indulged into relationships with white women, most commonly with their maids and slaves.

The image of the Southern belle finds its origin in the patriarchally organized society where beside a strong man there was a fragile and helpless woman whose role was to empower the man's feeling of confidence, strength and domination. In contrast to this a typical woman of the South (see above) was not inactive. On the contrary: she devoted her time to developing various skills that helped her take better care of the children and improve her housework activities. Moreover, those from lower and middle classes took to manual labor as well.

During the Civil War the expectations towards women changed considerably. It should be mentioned, though, that it was also the time they were living in that contributed to the change of their image. Magical and superior characteristics previously applied to them started to fade away and behind a gentle and beautiful face the reality of war constructed a woman, whose priorities lay with taking care of her husband and children, the wounded, running the plantations, education and the like. They became hard-working, responsible and more independent.

The South is at the core of William Faulkner's interest and he managed to research various characters in his work. His heroines differ from each other a great deal but when looked at in detail they share many similarities. The Southern belle etiquette can be attributed to them all but in various shapes and forms. Living in the South had a strong impact on their lives, they had to overcome many difficulties and face many challenges.

In Faulkner's Light in August from 1932 we meet Lena Grove, who at first sight might not seem a typical Southern belle for when we meet her she is an outcast whose connection with nature grows by the minute. Let us try to analyze her a bit closer to see where and to what quantity the elements of the beauty lie in her. Next in line is Joanna 
Burden, whose attempts to be accepted as a Southerner fail miserably for she is nevertheless seen as a Northerner. Mrs. Gail Hightower, McEachern, Amistad and Hines are minor characters but they also contribute to the story itself.

Lena's simplicity presents the main factor that prevents her from getting a wider insight into aristocracy and its life. The greatness stands hidden for her, but Faulkner nevertheless manages to include some signs that might hint at her wanting to be a part of high society. The only reference connected to her childhood shows Lena as a little girl, riding a carriage to town along with her father. Before climbing up she takes her shoes off, when they arrive to the town, she puts them back on again and walks a bit away from the carriage, making her father think she is worried about her shoes. The real reason, though, lies in the fact that she would like to be seen as a lady with urban origins rather than rural. This elevated style, the way she speaks and behaves comes to the upfront again when she feeds. Despite her blue dress being faded, Faulkner is attentive enough to notice the color of her hat brim matches the dress. But it is not only the clothes that show her wish to belong to high circles; it is also her behavior, shown in the way she talks to the Armistids: well-mannered although her choice of words is simple. She expresses praise and cannot stop thanking good people for their helpfulness and kindness, knowing she has neither the money nor the means to actually do it. The above-mentioned characteristics point to Lena's wish of being a lady - or at least look like one.

Unfortunately, though, her wishes and dreams do not come true due to her behavior and "wrong" roots that push her away from civilization. Her social position prevents her from becoming one of those lucky ladies who do not have to work for their survival and whose chores include taking care of maids or slaves, taking part in social gatherings and/or church ordeals. Together with her inappropriate social status, there is another obstacle, namely her attitude towards men, both towards Lucas Brown and towards her own brother. She lives with his family for many years, looks after his children, helps in his house and thus does not see her brother as the provider of his family. She finds it easy to leave his house and goes after her lover. It should be noted, though (as Faulkner notices too) that neither does her brother feel the need to protect Lena, take care of her or even try to keep her in his house. It was her wrong-doing that was responsible for her status. She betrayed her family and disgraced its name and almost brought it upon her to have to leave. Last but not least: she presented yet another hungry member to be fed.

Leaving home is a serious and difficult step she takes but she manages to find the courage and will needed to defend herself from the accusing society. Her way is taken with a mission: a mission to find her soul mate, to marry and take the traditional role of a woman in a marriage. Strong wishes aside, she turns Byron down at first, showing her fear of becoming clung to one man after marriage and lose the freedom she has been enjoying. She takes a personal decision to prolong her single days a bit more and to enjoy her time as a young individual with her own wishes, thoughts and ideas.

Joanna Burden, on the contrary, is quite a different character. She suffers no financial shortage and has all the characteristics of a Southern lady. One persisting problem in her life is presented by the fact that she cannot escape her roots. While true Southern belles can boast a long list of eminent predecessors, Joanna has none and her family appears an intruder in Jefferson. Her grandfather was a puritan from New Hampshire 
and did not leave a mark that would count in the South. Geographically speaking Joanna is born in the South but the society sees a Yankee in her.

However, she has many characteristics that pertain to Southern belles, such as: a high level of independence, courage, family pride she takes in, a dedication and understanding of male members of her family. Her grandfather, stepbrother and father are all deceased but still exercise strong influence on her decisions and her way of life. It is because of them that she gives up her role as a wife and a mother and rather takes a more active role in the struggle for the blacks' and for their ideas, principles and rights.

Compared to Lena's and Joanna's social status, Mrs. McEachern and Mrs. Armistid fall somewhere in the middle between the two. They are both wives of independent farmers whom they are committed and devoted to. It can be seen from Faulkner's descriptions that living in a marriage did not make Mrs. Armistid a submissive and obedient wife but she managed to remain an independent and stubborn woman who fights for her place and does not submit to her husband. Mrs. McEachern, on the other hand, has lost her independence and self-confidence through many years of marriage. Her strong husband and his different view of the world has taken its toll on her. Thus she remains far from the image of a fragile Southern belle whose strong and determined character lies within her.

Mrs. Armistid stands in her sharp contrast, she enjoys her husband's approval, is free to be religiously active, is known for her generosity and good manners and is at the same time a devoted wife, a loving and caring mother, a good housewife, a perfect personification of the ideal of the Southern Belle. She is s great woman from all angles. The only odd moment of doubt is arisen by the fact that her dominance outshadows her quiet and indecisive husband completely.

The image of a perfect wife has a major influence on Gail Hightower's wife. As a daughter of a distinguished professor Mrs. Hightower has spent her life in high society. She is educated, well-mannered and knows the society's expectations and demands in detail. She lives surrounded by a strictly limited circle of her father's friends and acquaintances, while marrying Hightower satisfies her wish to create her own life, removed from her parents.

Sadly enough, her decision to marry soon proves to be the wrong one for it does not open any opportunities she had been longing for. Prior to their wedding she is known for her loyalty and helping hand. She helps her husband-to-be get the long awaited job in Jefferson. This is what he has always wanted but is now unfortunately unable to amply repay her efforts. In the end Mrs. Hightower becomes a victim of her husband's church society and is unable to meet its expectations. The society demands loyalty, honesty, humility, sincerity, it expects an active involvement in church life, and expects her to be a perfect housewife and wife with all the qualities pertaining to the two titles. The burden society has placed on her shoulders is heavy to carry but she does not despair. Her independence is put to the test, yet she does not - in opposition to Mrs. McEachern - give in to the increasing pressure and to the patriarchal society. Her rebellion is shown through her sudden many trips to Memphis which remain unexplained till the novel's end. She fails to fulfill her duties as the minister's wife and shows no interest in her husband's services and sermons. To get a better and clearer understanding of her obligations, she is sent to a sanatorium but after her return does not change a bit and 
miserably ends her existence by committing suicide which at the time seems the only solution for her miserable life.

A very similar set of expectations and demands is put upon Mrs. Atkins and Bobby Allen but neither can express such rebellion as Mrs. Hightower. Each rebels in her own way, though. Bobby Allen defies her traditionally accepted role of a woman and wife by becoming a prostitute, while Mrs. Atkins seeks sexual satisfaction outside her marriage. Mrs. Atkins is another example of a character that has to fight for their position. She is in strong opposition to her husband's irrational behavior supported by religiously fanatic demands. When their grandson is born, she decides to protect him from his grandfather who is responsible for the boy's unmarried mother's death. Her struggle is everlasting and difficult.

And such is also Thomas Sutpen from Absalom, Absalom! (1951). His idea of a distinguished, magnificent and respected family goes terribly wrong and ends in failure. $\mathrm{He}$ is nevertheless constantly accompanied by an array of Southern belles: his second wife Ellen, daughter Judith and his sister-in-law (and almost his third wife) Rosa.

Ellen has a solid Southern belle basis: she was raised in a proper way, comes from a respected family and is admired by society. Her sister Rosa sees a strong woman in her and it is exactly this strength that helps her survive her wedding day fiasco. Her pre-arranged marriage is difficult to handle but her decision is firm: she will respect her husband no matter what. Her fellow villagers boycott her wedding, there is great sadness inside her, and she is struggling not to break down. Faulkner is sarcastic about wedding day preparations and feelings: "Maybe women are even less complex than that and to them any wedding is better than no wedding and a big wedding with a villain preferable to a small one with a saint" (Faulkner 1987: 61).

As a wife she follows the patriarchally oriented Southern society and accepts her husband's outbursts of anger, physical violence and cheating with slaves, the product of which are his illegal children. The shocking part is that Ellen takes one of them and raises her as her own child. She is always obedient and does not dare to contradict her husband. She only does it ones: when she sees her daughter missing, goes looking for her and finds her in the barn where she can see Thomas fighting and their son looking in order to see what it takes to become a real man, as his father believes. Her reaction is spontaneous and filled with fear for her daughter's well-being, for her innocence and purity. At the same time it is an expression of her devoted motherhood.

The readers follow her transition from a fearful and worried young wife to another period during which she glows and lives like a true Southern belle. Southern society loves her, accepts her and her children as their own and shows them respect accordingly. It looks as if it could not get any better. But Rosa feels there is more to this story:

If she had had the fortitude to bear sorrow and trouble, [she] might have reason to actual stardom in the role of the matriarch, arbitrating from the fireside corner of a crone the pride and destiny of the family, instead of turning at the last to the youngest member of it and asking her to protect the others. (83)

Ellen Coldfield Sutpen is a Southern belle whose life is a rollercoaster ride. She has many characteristics pertaining to the ideal of the Southern belle but they are not 
enough. Despite being an understanding and obeying daughter, a devoted wife, a loving mother and a church devotee this does not assure her longtime happiness. The tragedy of her life is balanced alongside the story of the South's past. Antebellum South found praise for (outside) image, family pride and society's well-being, all put way ahead of the woman's feelings and happiness.

Her daughter Judith Sutpen is another character who symbolically points at the struggle and sacrifice of a Southern belle during the Civil War. Idyllic youth filled with love, tenderness and attention are followed by the cruelty of war when she is suddenly faced with a completely different situation. She is the one who has to take care of the house, she has to learn the housework and various skills to be able to survive. There is neither hesitation nor self-pity in her behavior. If her life in the Antebellum South was dull and empty, it is now filled with new responsibilities and duties, and is as such varied and full of challenges.

There is power inside her that comes to the prominence after the murder of her fiancé and her brother Charles flees to escape the punishment and she is left alone. Strength, dignity and courage stand hand in hand to help her survive the hardships of war and personal loss. Moreover, she is strong enough to welcome Charles's son and her octoroon mistress in her house. On top of it all, she even accepts their son Charles Etienne as if he were her own. The love she gives is by all means way bigger and deeper than the one shown from Mrs. Compson in Faulkner's The Sound and the Fury (1929) seen below. The situation changes completely when her dad returns from war. Then a sudden transformation takes place - transformation that makes her a timid, shy and scared woman whose position is again controlled by the patriarchal Southern society and it expectations.

Rosa Coldfield is another example of a Southern belle. She is an educated woman who at first lives with her father and spends quite some time writing poetry. During the war she moves to her brother-in-law's house where she lives with her niece. She is faced with an indecent proposal when offered to marry him but beforehand having a sexual intercourse to prove her being able to bear his babies. She turns him down, of course, and is left deeply hurt and humiliated. Her life changes considerably, she never seems to find happiness again. She returns to a collapsing house where her feelings of shame, sadness, weariness and despair multiply. She is unable to find balance in her life, her future looks gloom and she is aware of this. The misery grows as years go by and she is stigmatized forever.

Moreover, her Aunt who used to take care of the housekeeping escapes one day and thus leaves Rosa alone. She needs to learn how to do the housework in order to survive. She is only successful at it for she leaves all the financial matters to her father due to her inability to see the importance of money. Life has played a trick on her and Faulkner reveals her bitter life story page by page. When her father dies, she has to live by other citizens' friendly donations and somehow she manages to live a decent life.

It should be noted, though, that Rosa does everything she can to retain the image of a proper lady and behaves accordingly. She is unable to meet the expectations of a patriarchal society completely because she does not marry. But she does submit to its demands and is perfectly aware of her position as an unmarried woman in the South. What is more, she even accepts its help in a silent way for acknowledging it openly 
would be a loud and outspoken critique of her late father's inability to provide for her appropriately. The Coldfields' position in Southern society would be hurt and therefore she does everything she can not to comment on the subject. Her dignified behavior and her concern for the respect of her family name place her among Southern belles.

Out of the three heroines from the novel The Sound and the Fury (1929), only two can compete to find themselves among the Southern belles, while Dilsey does not fulfill the race criterion and must be ruled out immediately, the two remaining being Mrs. Compson and Caddy. The former is ready to do almost everything to become and remain a true woman of the South. She does have a special attitude towards it, though. Her understanding of the belle's characteristics is limited and she shares the opinion that her frailty and weakness are the only necessary qualities that enable her to belong to this group. She casts aside other much more important issues, such as a complete devotion to both, her husband and to the patriarchal system. Needless to say, she shows neither love nor affection for her children.

She is not a good wife and she fails as a mother. Her feelings and emotions are strictly limited to one side of her family, namely the Bascombs, whereas the Compsons do not deserve her time. She does not equate family with either love or protection but rather with blood and reputation. Thus she shows absolutely no affection for her children but idolizes Jason because she sees a Bascomb in him. She is a weak shallow woman obsessed with herself and her family's social position.

She spends most of her time in her bedroom, yelling useless and pathetic comments to Dilsey. She keeps complaining about her health and feels sorry for herself. She in a way symbolically represents the Compsons' decaying house which is off the beaten social path. Mrs. Compson is far from an image of an ideal Southern belle for her obsession with her own self moves her away from the society and the reality of the world. All her (possibly) good qualities fade away and are hidden to the reader to either feel or see. She is unable to continue the expected pattern from her ancestors because she cannot adapt to the constantly changing modern world but rather sticks to her vision of the world and her role in it.

As the complete antithesis to her mother, Caddy is strong, compassionate, tender and independent. Faulkner adored her and she was his heart's darling and one of his favorite characters which he often pointed out in interviews. She is the epitome of beauty and Southern elegance, and she is strong enough to escape the traps of the past through her purity, innocence and simplicity. She acts according to the topic: she is chatty and lively when her brother Benjy is the subject of the talk but is quiet and shy when her fate is in the focus point. She does not want to have her feelings and emotions out in the public eye and so tries to keep her position in society.

She does fail considerably, though, because of her sexual advances at men. She sees how Victorian society managed to disfigure her mother's character and personality and deep inside knows she will not follow her way. She seeks many sexual relationships in her adolescence, which is frowned upon by society and by her family too. When she defies the convention to assert her selfhood, all male members show openly their disapproval: her father finds comfort in alcohol abuse, Quentin insults Dalton Ames, then begs her not to marry Herbert Head and as a culmination of everything commits suicide. Benjy responds by howling and shouting. Disapproval is shown by Jason as well 
- both towards Caddy and towards her daughter whom she uses to avenge her sister's sins. Caddy becomes a fallen woman who is not allowed to visit her parental home and the very mention of her name is forbidden by her mother.

Caddy's weakness is shown in her passive approval of and agreement with the pre-arranged marriage and reaches its highest point when she gives up her right as a mother, believing she is not good enough to raise her own daughter. At the same time her surrender is a result of her low self-esteem, accompanied by low self-respect. Needless to say, her patched-together marriage occurs to hide the fact that she is pregnant. She does not find happiness or respect in her married life. She feels "ashamed of herself as a natural woman with emotional and sexual desires" (Tao 2000: 1).

She could have reached the belle ideal and met everyone's expectations but it is Southern society that prevents her from it. She is a loser in her rebellion against male convention. When her feelings are at stake, the society does not hesitate to point out how inappropriate they are. Her family does not help either and so love is lost for her. If she had had one more chance, I am sure she could have led a better, fulfilled life where she would be recognized as a loving mother and devoted wife.

Drusilla from The Unvanquished is quite a different character who adopts many male characteristics. Her wish to fight in the civil war makes her opt for male clothes and cuts her hair. Moreover: her behavior and rhetoric change accordingly. Her wish comes true when during the battle she rides alongside her future husband, John Sartoris. She possesses courage and fearlessness that prevail in her personality. After the war the two marry and John eventually manages to persuade her to become more feminine again. Nevertheless, she remains unfeminine and brave inside. The reader gets the feeling that it is a man by John's side and not his wife, for they are treated equally and share the same characteristics.

"The Odor of Verbena" is the most prominent story of the novel. It focuses on Drusilla's loss of her husband and her life afterwards. She wants to take his authoritative role and act according to the code of honor, still very much present in 1874. She hands her stepson Bayard two guns, kisses him goodbye and expects him to avenge his father's death. When he silently refuses to do so, Drusilla is left devastated and shocked for it is the first time her authoritative attitude has not met her expectations. The feeling of her own unimportance and frailty push her into hysterics, she flees town way before Bayard returns from the duel where he had gone unarmed.

Drusilla is unable to grasp the extension of Bayard's dilemma. Drusilla and the Southern society on one hand, his knowing that yet another victim would not make things better on the other. At the age of 17 he had already committed crime when he and his friend shot a man who was trying to rob his father. The deed has provided him with neither satisfaction nor relief.

The devastating year of Drusilla's life affect her enormously, both the war and her husband's death are tragic events that force her to do her best and show her courage, devotion and act according to the code of honor. Despite her strong personality, she is shown as a torn and destroyed person in the end, filled with despair and disappointment. Her courage is commented on by Faulkner, she rides "in man's clothes and with her hair cut short like any other member of [Sartoris'] troop, across Georgia and both Carolinas in front of Sherman's army" (Faulkner 1959: 167). She does, however, show 
her gentle side when she leaves a verbena on Bayard's pillow. The verbena is a symbol of courage, "that odor which she said you could smell alone above the smell of horses" (Faulkner 1959: 167). By doing so she shows her agreement with his reaction and her approval of his courage and honor.

Drusilla's impulsiveness and her strength of character do not put her into the Southern belle category. Historians did approve of brave and fearless women of the South, but there were not many who rode by the side of the Confederacy for sure. Many positive characteristics of the belle define her personality but there are numerous she does not possess. She is by no means feminine and gentle. She accepts her husband's dresses merely as a gift and by wearing them shows her respect and love for him. She is quite aggressive in her reactions towards her stepson's decisions. A true lady would accept him as he is and not object. In the end she escapes his decision rather than accepts it.

Aunt Jenny, on the contrary, understands his nephew's dilemma. She shows a calm poise, her composure, sincerity and obedience fit into the Southern belle description perfectly. She knows Bayard well enough to see the extension of his distress after his father's death. Traumatic feelings he is faced with have a history and she is strongly aware of it. Jenny offers him a different, more realistic view of the world. It is not so much about the advice or support she gives but more about the knowledge that she will always be there for him, no matter what.

Linda from Faulkner's novel The Town (1957) is an example of a rather untypical Southern belle. Being an illegitimate daughter of Eula Varner and her lover, life puts various tests and challenges along her way. Her mother's miserable love life ends in suicide, commented on by V. K. Ratliff: "She loved, had the capacity to love, to give and to take it. Only she tried twice and failed twice not just to find somebody strong enough to deserve it but even brave enough to accept it" (Faulkner 1957: 150). After her mother's death Linda departs for New York where she marries a Jewish communist, they fight in the Spanish war where she loses both her husband and her hearing. Her wish to stop the racial segregation at school is another turning point in her life, showing her uniqueness and rebellion.

After her return from war she finds a job in Jefferson and support in Gavin who had been in love with her mother Eula but Flem led her away from him. Now Gavin is falling in love with Linda who knows that these kinds of feelings were the ones she had been waiting for all her life: "I know now I've never really had anybody but you. I've never really even needed anybody else" (Faulkner 1957: 420). And she is exactly like her mother: "needing, fated to need, to find something competent enough, strong enough [...] to take what she had to give; and at the same time doomed to fail" (Faulkner 1957: 233). Unfortunately, Linda remains alone and miserable for Gavin marries another woman - a widow.

Last but not least, there is Emily from Faulkner's short story entitled "A Rose for Emily" from 1954. She seems a true Southern belle at first: during her youth she is a girl her father is proud of. Her innocence, sweetness, purity, tenderness and frailty point at her belle-like status. Sadly though, some of her actions show another side of her personality and the expectations of the Southern society are not met at all.

After her father's death Emily leads a solitary life, not showing any feelings of sadness, sorrow or regret. She fails miserably when she finds out Homer has no inten- 
tions whatsoever to marry her. She hides her feelings and becomes a different person. She decides to take control of her life. She does not answer the pharmacist's question about why she is buying poison. Her little victory is shown in the fact that he sells her arsenic without asking any further questions.

Her strength of character and behaving according to the Southern belle code is displayed at an unpleasant topic of tax payment. She manages to persuade all the city notabilities that she will not pay them. She rejects the seniors and the mayor and sends out a clear message that says she will not submit to their wishes and commands. The society feels that "Miss Emily had been a tradition, a duty, and a care; a sort of hereditary obligation upon the town" (Faulkner 1954: 489).

She is left alone and her image is characterized "with a vague resemblance to those angels in colored church windows-sort of tragic and serene" (Faulkner 1954: 493). The money her father had left her, slowly but steadily melts away and therefore she is forced to earn some, which she does by teaching porcelain painting. Southern society does want to get involved and help her through her rough times but she will not let them. They feel the need to offer a helping hand after the loss of her father. Moreover, they share the opinion that her father's death should not affect her in the way to accept Homer who is below her aristocratic status. It is exactly this group of people who start questioning her health, making parallels with her aunt's poor mental state.

When looked at in detail, Emily's true nature springs out: there is a manipulative woman hidden behind a perfect Southern belle image. She is devising new schemes behind the locked door: "She passed from generation to generation-dear, inescapable, impervious, tranquil, and perverse" (Faulkner 1954: 496). It is with utmost thoughtfulness and accuracy that she has been poisoning Homer, her lover. Thus her moral strength is questioned and sapped. She is driven by her motives and she lives by the self-made rules which are not controlled by the society at all.

She finds refuge behind the Southern code of honor and pride where her mean behavior is hidden and her image of a perfect Southern belle safe. She takes her secret to the grave, leaving the Southern society with the idea that she has been one of the last remaining jewels of the South. Reality is different, of course, but it is only the reader who knows it (besides Faulkner and Emily, of course). Emily has failed miserably at the test of purity and perfection and there are many reasons for it, the most prominent being the role of her father. By being highly possessive towards her, he isolated her from the rest of the world and therefore made it impossible for her to either love or be loved. As a consequence Emily chose to live in isolation. Maybe some of the reasons for her fall may lie in her genetic predisposition as well: her aunt's problems.

The reasons for her behavior lie in Emily herself, as well as in her relatives and in the society which affects a person through its expectations, demands and actions. Catastrophic results ruin certain characters and affect their lives in ways they did not even dare to think about. It is via Emily and other heroines that Faulkner wanted to show criticism of the antebellum Southern society that interfered with women's lives and destinies. The social stereotype of a perfect woman of the South in his works is confronted with difficulties and often disappointment and failure.

As already mentioned Faulkner's female characters do not come across as perfect representatives of the South but it can be held true that they come close to them with 
some personality characteristics and behavior. The decaying Southern society is shown through Faulkner's heroines. Despite many positive and worthy qualities that praise the ideal image of a woman, these same qualities can have a dual effect and at the same time destroy them and push them in despair, disappointment and weakness that eventually ends in a tragic and sad conclusion. Social norms, unreal and unattainable wishes, demands and expectations that women cannot meet nor fulfill, bring unwanted consequences not only for the woman herself but also for her closer and wider society.

The patriarchal Southern society and its idolizing the perfect Southern belle does much damage to these women who cannot meet all the expectations and fail to act out their role as a perfect belle. They carry in them many qualities that help them live, survive and keep a position in the then society. Their signifying features include pride, a strong will, the appropriate upbringing, good manners, education, a sense of morality and religious activity. Trying hard to confront all the challenges of the changing society they may suffer considerably and many end up miserable, broken, forgotten and lost.

Faulkner's novels unveil "the anguish and suffering of women in the South and expose the role of the patriarchal society and culture in constricting, defining, shaping and controlling the [belles] (Tao 2000: 2). We experience different types of women that shed light on different aspects of the novels and have different roles. They are in fact hints, all in their own manner, of the changing and decaying South.

Ljubljana, Slovenia

\section{WORKS CITED}

Faulkner, William. "A Rose for Emily." The Faulkner Reader: Selections from the Works of William Faulkner. New York: The Modern Library, 1954. 489-497. Absalom, Absalom! 1951. New York: Vintage Books, 1987. Light in August. 1932. New York: The Modern Library, 1950. The Sound and the Fury. 1929. London: Everyman Publishers, 2000.

The Town. New York: Random House, 1957.

The Unvanquished. 1934. New York: Random House, 1959.

Jones, Anne Goodwyn. "Belles and Ladies." Encyclopedia of Southern Culture. Ed. Charles Reagan Willson, William Ferris and Ann J. Adadie. Chapel Hill: The University of North Carolina Press, 1989. 1527-30.

"Southern Belle." Wikipedia: The Free Encyclopedia. Wikimedia Foundation, Inc. June 7 2011. Web. June 8 2011. <http://en.wikipedia.org/wiki/Southern_belle>

Tao, Jie. "Repressed Voices: Faulkner's Three Female Characters." The Faulkner Journal of Japan. 2000. Web. May 22 2011. <http://www.soc.nii.ac.jp/wfsj/journal/No2/TAO.htm>

The article is based on the author's Ph.D. thesis, which was supervised by Professor Igor Maver. 